\title{
The rrs (16S)-rrl (23S) ribosomal intergenic spacer region as a target for the detection of Haemophilus ducreyi by a heminested-PCR assay
}

\author{
X. X. Gu, ${ }^{1}$ R. Rossau, ${ }^{2}$ G. Jannes, ${ }^{2}$ R. Ballard, ${ }^{3}$ M. Laga ${ }^{1}$ and E. Van Dyck ${ }^{1}$ \\ Author for correspondence: X. X. Gu Tel: +32 324765 36. Fax: + 3232476333. \\ e-mail:guxiaoxiao@hotmail.com
}

\footnotetext{
1 Department of Microbiology, Institute of Tropical Medicine, Nationalestraat 155, 2000 Antwerp, Belgium

2 Innogenetics NV, Ghent, Belgium

3 STD/HIV Research Unit, South African Institute of Medical Research, Johannesburg, South Africa
}

\begin{abstract}
The intergenic spacer region between the rrs and rrl ribosomal RNA genes of Haemophilus ducreyi was analysed and the DNA sequence was used for the selection of specific PCR primers. A highly sensitive and specific heminestedPCR assay for the identification of $H$. ducreyi was developed. The assay showed a sensitivity of $96 \%$ on genital ulcer specimens from patients with clinically diagnosed chancroid, compared with a sensitivity of $56 \%$ for culture methods. These results indicate that this PCR assay has the potential to become an accurate and easy reference method for the detection of $\boldsymbol{H}$. ducreyi.
\end{abstract}

Keywords: $r r s \sim r r l$ spacer, Haemophilus ducreyi, chancroid

\section{INTRODUCTION}

Haemophilus ducreyi, the causative agent of chancroid, is a major cause of genital ulcer disease (GUD) in developing countries. In Africa, Latin America and Southeast Asia, chancroid may account for 10 to $40 \%$ of sexually transmitted disease (STD) clinic visits (Kreiss et al., 1989; Morse, 1989; Ortiz-Zepeda et al., 1994). Especially in South Africa, chancroid is a leading infection in men with GUD, with $H$. ducreyi being isolated from $40-68 \cdot 3 \%$ of persons with STDs (PhamKanter et al., 1996). GUDs are independent risk factors for human immunodeficiency virus (HIV) infection (Jessamine et al., 1990; Plummer et al., 1991; Grosskurth et al., 1995). GUDs include syphilis, genital herpes, chancroid, lymphogranuloma venereum, and donovanosis. A diagnosis based solely on clinical presentation has an accuracy of $22-80 \%$ because of atypia, mimicry and coinfection (Choudhary et al., 1982; Fast et al., 1984; Taylor et al., 1984; Dangor et al., 1990, 1993; Trees \& Morse, 1995). A definite diagnosis of chancroid is based on isolation of $H$. ducreyi, a fastidious organism requiring complex media and specific conditions for

Abbreviations: ISR, intergenic spacer region; GUD, genital ulcer disease STD, sexually transmitted disease.

The GenBank accession numbers for the nucleotide sequences reported in this paper are Y11738 for HD CIP $542^{\top}$ and Y11717 for HD ITM 5600. growth, making culture difficult and time-consuming and resulting in a sensitivity that varies from 69 to $84 \%$ in experienced laboratories (Dangor et al., 1990, 1993; Trees \& Morse, 1995).

Non-culture methods using polyclonal and monoclonal antibodies for antigen detection, with immunofluorescence or enzyme immunoassays, have been described by several groups and compared with clinical diagnosis, culture, or nucleic-acid-based detection systems. The accuracy of these tests is not well known (Karim et al., 1989; Roggen et al., 1993; Ahmed et al., 1995). The detection limit of $10^{4}$ c.f.u. observed with monoclonal antibodies and with DNA probes is a major drawback for the detection of $H$. ducreyi in clinical specimens. Also, inter-study comparisons of test sensitivities are difficult when the denominator is 'the number of patients with chancroid', since the validity of that number depends on the accuracy of the clinical diagnosis. PCR offers a more sensitive approach for detecting low numbers of organisms in clinical specimens. Several PCR assays targeting different DNA sequences have been described for the diagnosis of chancroid (Chui et al., 1993; Johnson et al., 1994, 1995; Parsons et al., 1995; West et al., 1995; Orle et al., 1996). A highly sensitive, easy and very specific diagnostic approach may be the use of the $r r s-r r l$ intergenic spacer region (ISR) as a target for DNA amplification to identify pathogenic bacteria at the genus or species level (Barry et al., 1991; Jensen et al., 1993). 
Table 1. Micro-organisms used in this study

\begin{tabular}{|c|c|c|c|}
\hline Micro-organism & Origin & $n$ & Reference $^{*}$ \\
\hline \multicolumn{4}{|l|}{ Haemophilus ducreyi } \\
\hline \multicolumn{4}{|l|}{ Reference strains } \\
\hline & Vietnam & 1 & $\mathrm{CIP} 542^{\mathrm{T}}$ \\
\hline & USA & 4 & V 1168,$1169 ;$ CF 103,104 \\
\hline & Sweden & 5 & EF $7311,7781,7829,9276,10045$ \\
\hline \multicolumn{4}{|l|}{ Clinical isolates } \\
\hline & Zaire & 9 & ITM 5565 to ITM 5573 \\
\hline & South Africa & 7 & ITM 5594 to ITM 5600 \\
\hline & Senegal & 4 & ITM 5629 ; ITM 5631 to ITM 5633 \\
\hline & Rwanda & 9 & $\begin{array}{l}\text { ITM } 5701,5702,5704,5708,5710,5716 ; \\
\text { ITM } 5718 \text { to ITM } 5720\end{array}$ \\
\hline & Ivory Coast & 9 & ITM 5800 to ITM 5808 \\
\hline & The Gambia & 6 & ITM 5604 to ITM 5609 \\
\hline & The Netherlands & 2 & ITM 3125, 3130 \\
\hline & Thailand & 4 & ITM 3515 ; ITM 3519 to 3521 \\
\hline & France & 3 & ITM 3294 to ITM 3296 \\
\hline & Mexico & 1 & ITM 3533 \\
\hline & Kenya & 5 & ITM 2619, 2683, 2684, 2695, 2696 \\
\hline \multicolumn{4}{|l|}{ Non-Haemophilus ducreyi } \\
\hline Neisseria gonorrboeae & & 2 & ITM 92-502989, 92-502990 \\
\hline Haemophilus influenzae & & 4 & ITM $4772,4473,4475,5252$ \\
\hline Haemophilus aegyptius & & 1 & ITM 859 \\
\hline Haemophilus aphrophilus & & 1 & ITM 5323 \\
\hline Haemophilus haemolyticus & & 1 & ITM 1451 \\
\hline Haemophilus parahaemolyticus & & 1 & ITM 999 \\
\hline Haemophilus parainfluenzae & & 1 & ITM 1437 \\
\hline Haemophilus somnus & & 1 & ITM 3610 \\
\hline Haemophilus equigenitalis & & 1 & ITM 3611 \\
\hline Taylorella equigenitalis & & 1 & ITM 2068 \\
\hline Pasteurella gallinarum & & 1 & ITM 1937 \\
\hline Pasteurella haemolytica & & 1 & ITM 1639 \\
\hline Pasteurella multocida & & 1 & ITM 4927 \\
\hline Pasteurella pneumotropica & & 1 & ITM 1299 \\
\hline $\begin{array}{l}\text { Pasteurella multocida } \\
\text { subsp. septica }\end{array}$ & & 1 & ITM 1065 \\
\hline Pasteurella ureae & & 1 & ITM 243 \\
\hline Yersinia pseudotuberculosis & & 1 & ITM 34 \\
\hline Actinobacillus bominis & & 1 & ITM 3167 \\
\hline $\begin{array}{l}\text { Actinobacillus } \\
\text { actinomycetemcomitans }\end{array}$ & & 1 & ITM 1276 \\
\hline Gardnerella vaginalis & & 1 & ITM 3334 \\
\hline Escherichia coli & & 1 & ITM 1695 \\
\hline Staphylococcus aureus & & 1 & ITM 8 \\
\hline Bacillus subtilis & & 1 & ITM 37 \\
\hline Streptococcus faecalis & & 1 & ITM 5458 \\
\hline Streptococcus faecium & & 1 & ITM 5052 \\
\hline Lactobacillus acidophilus & & 1 & ITM 1033 \\
\hline Candida albicans & & 1 & ITM C31 \\
\hline Treponema phagedenis & & 1 & ATCC 27087 \\
\hline Chlamydia trachomatis LGV2 & & 1 & ITM X33 \\
\hline Herpes simplex virus type II & & 1 & ITM X34 \\
\hline
\end{tabular}

*CIP, Collection de l'Institut Pasteur, Paris, France; ITM, Institute of Tropical Medicine, Antwerp, Belgium; EF, collection of the University of Göteborg, Department of Microbiology, University of Göteborg, Sweden; V and CF, collection of the University of Washington, Department of Microbiology, University of Washington, Seattle, USA; ATCC, American Type Culture Collection, Rockville, MD, USA; T, type strain. 
In this study we have investigated and characterized the $r r s-r r l$ ISR from the type strain of $H$. ducreyi, CIP $542^{\mathrm{T}}$ and from a recent $H$. ducreyi clinical isolate (ITM 5600). Specific primers were selected to develop a heminestedPCR strategy for the detection of $H$. ducreyi in clinical specimens.

\section{METHODS}

Micro-organisms, clinical specimens and culture conditions. All micro-organisms used in this study (Table 1) were selected from our own culture collection and were cultivated on appropriate media according to standard procedures except Chlamydia trachomatis LGV2, Herpes simplex virus type 2 and Treponema phagedenis (ATCC 27087) isolated from human syphilis. The genital ulcer specimens were obtained from miners with a clinical diagnosis of chancroid attending an STD clinic at the Leslie William's Memorial Hospital in Carletonville, South Africa. Culture of these samples was performed at the South African Institute for Medical Research as described previously (Dangor et al., 1992). Swabs from the ulcers were stored dry in cryovials at $-70^{\circ} \mathrm{C}$ and transported to Antwerp on dry ice.

Negative control groups. Swabs from 32 patients with nongenital ulcers caused by different micro-organisms were collected at Benin and Togo in Africa. Genital swabs from 19 patients with non-chancroid STDs and vaginal swabs from 21 healthy females were collected at the STD clinic of the Institute of Tropical Medicine in Belgium.

DNA Extraction. Cultured cells were lysed by heating at $95^{\circ} \mathrm{C}$ in $0.05 \mathrm{M} \mathrm{NaOH}$ for $10 \mathrm{~min}$. After cooling to room temperature, $0.1 \mathrm{vol} 1 \mathrm{M}$ Tris $/ \mathrm{HCl}(\mathrm{pH} \mathrm{8.0)}$ was added. For the clinical samples, $0.5 \mathrm{ml}$ MilliQ water was added to the swabs and the vials were shaken for $30 \mathrm{~min}$ at 1000 r.p.m. The swabs were then squeezed and removed. A volume of $95 \mu \mathrm{l}$ was lysed by adding $5 \mu \mathrm{l} 1 \mathrm{M} \mathrm{NaOH}$ and heating at $95^{\circ} \mathrm{C}$ for $10 \mathrm{~min}$. After cooling, $10 \mu \mathrm{l} 1 \mathrm{M}$ Tris $/ \mathrm{HCl}(\mathrm{pH} 8.0$ ) was added. For amplification, $5 \mu$ l lysed specimen was added to $20 \mu \mathrm{l}$ PCR mixture.

Amplification and direct sequencing of the rrs-rrl ISR. The primers used to amplify the spacer region were selected from conserved sequences in the $r r s$ and $r r l$ rRNA genes (Rossau et al., 1991). Primer U1 was selected at the $3^{\prime}$ end of rrs and primer R 1 corresponded to position $60-44$ of the $r r l$ sequence (Table 2). Bacterial DNA (50 ng) was amplified using $1 \mu \mathrm{M}$ of both primers in a $50 \mu \mathrm{l} \mathrm{PCR}$ mixture containing $50 \mathrm{mM} \mathrm{KCl}$, $10 \mathrm{mM}$ Tris/ $\mathrm{HCl}$ (pH 8.3), $1.5 \mathrm{mM} \mathrm{MgCl}_{2}, 200 \mu \mathrm{M}$ each of the four deoxynucleotide triphosphates, and $2.5 \mathrm{U}$ DNA polymerase (AmpliTaq, Perkin Elmer). After a first denaturation at $95^{\circ} \mathrm{C}$ for $1 \mathrm{~min}$, the reactions were cycled to $94{ }^{\circ} \mathrm{C}$ for $30 \mathrm{~s}, 55^{\circ} \mathrm{C}$ for $30 \mathrm{~s}$, and $72{ }^{\circ} \mathrm{C}$ for $30 \mathrm{~s}$ for a total of 30 cycles with a final extension step at $72^{\circ} \mathrm{C}$ for $7 \mathrm{~min}$, using a GeneAmp 9600 thermal cycler (Perkin Elmer). After purification on spin columns (Qiaquick PCR purification kit, Qiagen), the PCR products were sequenced using the ABI PRISM dye terminator cycle sequencing kit (Applied Biosystems) and analysed on an ABI 373 DNA sequencer.

Amplification and sequencing after cloning. The primers used were U1 (described above), and R2 corresponding to position 478-458 of the $r r l$ gene (Table 2). H. ducreyi bacterial DNA $(50 \mathrm{ng}$ ) was amplified using $0.8 \mu \mathrm{M}$ of both primers in a final volume of $25 \mu \mathrm{l}$ PCR mixture (compare with above) and $1 \mathrm{U}$ AmpliTaq DNA polymerase. The PCR conditions were as follows: a denaturation step at $94^{\circ} \mathrm{C}$ for $3 \mathrm{~min} ; 32$ cycles of $94^{\circ} \mathrm{C}$ for $1 \mathrm{~min}, 55^{\circ} \mathrm{C}$ for $1 \mathrm{~min}$, and $72^{\circ} \mathrm{C}$ for $1 \mathrm{~min}$; followed by a final extension step at $72^{\circ} \mathrm{C}$ for $7 \mathrm{~min}$. Amplified products were cloned using the TA cloning kit (Invitrogen). Full-length clones were detected by a rapid alkaline lysis method, restriction analysis, and agarose gel electrophoresis as described by Sambrook et al. (1989). Plasmid DNA was purified using the plasmid mini-kit (Qiagen). Both strands of the plasmid insert DNA were sequenced with the M13 universal and reverse primers (Table 2) using the Sequenase fluorescent labelled primer cycle sequencing kit (Amersham). The products were analysed on an ALF DNA sequencer (Pharmacia).

ISR heminested PCR. For diagnostic purposes, a one-tube heminested PCR was developed to amplify part of the $r r s-r r l$ ISR using two outer primers (PS1 and PS3) and one inner primer (PS2)(Table 2). The sequence of primers PS1 and PS3 correspond to positions 50-68 and 326-309 of the ISR, respectively (Fig. 1). The sequence of primer PS2 corresponds to position 246-223 of the ISR (Table 2). Either $50 \mathrm{ng}$ bacterial DNA or $5 \mu$ lysed clinical specimens was amplified using $0 \cdot 8 \mu \mathrm{M}$ PS1, $0 \cdot 2 \mu \mathrm{M}$ PS3 and $0 \cdot 6 \mu \mathrm{M}$ PS2 in a final volume of $25 \mu \mathrm{l}$. PCRs contained $16.6 \mathrm{mM}\left(\mathrm{NH}_{4}\right)_{2} \mathrm{SO}_{4}, 67 \mathrm{mM}$ Tris $/ \mathrm{HCl}$ (pH 8.8), $10 \mathrm{mM} \beta$-mercaptoethanol, $6.7 \mu \mathrm{M}$ EDTA, $17 \mu \mathrm{g}$ BSA ml ${ }^{-1}, 5 \%(\mathrm{v} / \mathrm{v})$ DMSO, $1.5 \mathrm{mM} \mathrm{MgCl}_{2}, 200 \mu \mathrm{M}$ each deoxynucleotide triphosphate, and 1 U AmpliTaq DNA polymerase. After an initial denaturation step of $94^{\circ} \mathrm{C}$ for $3 \mathrm{~min}$, the reactions were cycled 10 times to $94^{\circ} \mathrm{C}, 55^{\circ} \mathrm{C}$ and $60^{\circ} \mathrm{C}$ for $1 \mathrm{~min}$ at each step, followed by 35 cycles at $94^{\circ} \mathrm{C}, 50^{\circ} \mathrm{C}$ and $60^{\circ} \mathrm{C}$ for $1 \mathrm{~min}$ at each step, with a final extension at $72{ }^{\circ} \mathrm{C}$ for $7 \mathrm{~min}$.

rrs PCR. For comparison and confirmation, the one-tube nested $H$. ducreyi rrs PCR described by West et al. (1995) was

Table 2. Sequence of primers used for PCR amplification and sequencing

\begin{tabular}{|lll|}
\hline Name & \multicolumn{1}{c|}{ Sequence $\left(\mathbf{5}^{\prime}-\mathbf{3}^{\prime}\right)$} & \multicolumn{1}{c|}{ Target (position) } \\
\hline U1 & TGGGGTGAAGTCGTAACAAGGTA & $r r s(1441-1463)$ \\
R1 & CACGTCCTTCATCGCCT & $r r l(60-44)$ \\
R2 & CCTTTCCCTCACGGTACTGGT & $r r l(478-458)$ \\
M13 universal & GTAAAACGACGGCCAGT & M13 cloning vector \\
M13 reverse & TTCACAGGAAACAG & M13 cloning vector \\
PS1 & GACAAGTCGGAATACATCT & ISR (50-68) \\
PS2 & GATTACTCAGACTTTCTACTTTAG & ISR (246-223) \\
PS3 & TATGCGCGAGGCATATTG & ISR (326-309) \\
\hline
\end{tabular}


slightly modified. We used $0.4 \mathrm{nM}$ of outer primers HD996 and HD1400, and $480 \mathrm{nM}$ of inner primers HD1078 and HD1279 in a final volume of $25 \mu \mathrm{l}$. The amplification reaction was performed in two consecutive phases of 10 and 37 cycles.

Agarose gel electrophoresis. PCR products were separated by agarose gel electrophoresis on $2 \%(\mathrm{w} / \mathrm{v})$ agarose gels, and visualized by UV transillumination after ethidium bromide staining.

\section{RESULTS}

\section{Sequence analysis of the rrs-rrl ISR}

The sequence of the $r r s-r r l$ ISR from the type strain of H. ducreyi, CIP $542^{\mathrm{T}}$, was determined by direct cycle sequencing. For $H$. ducreyi isolate ITM 5600, sequencing of PCR products and five individual recombinant plasmids was performed. All sequences obtained for ITM 5600 were identical, and differed from the CIP $542^{\mathrm{T}}$ sequence by a single nucleotide, at position 328 of the sequence (Fig. 1). The $r r s-r r l$ ISR of H.ducreyi consisted of $347 \mathrm{bp}$ containing a single tRNA ${ }^{\text {Glu }}$ gene $(76 \mathrm{bp})$. The $\mathrm{G}+\mathrm{C}$ content was $37.2 \mathrm{~mol} \%$ and $37.5 \mathrm{~mol} \%$ for CIP $542^{\mathrm{T}}$ and ITM 5600, respectively.

\section{Heminested ISR and rrs PCR}

A fragment of $277 \mathrm{bp}$ was amplified with the outer primers PS1 and PS3, and an internal fragment of $197 \mathrm{bp}$ was amplified with primers PS1 and PS2 (Fig. 2). As estimated by the agarose gel band intensity of PCR products originating from $H$. ducreyi genomic DNA diluted from $50 \mathrm{ng}$ to $5 \mathrm{fg}$ (Fig. 3), the detection limit of this heminested PCR was $50 \mathrm{fg}$ input DNA, which, according to the genome size of $H$. influenzae (Fleischmann et al., 1995), accounts for approximately 25 genome-equivalents.

The sensitivity and specificity of the ISR heminested PCR were determined using 69 strains and clinical isolates of $H$. ducreyi, and 34 non- $H$. ducreyi reference strains selected among species belonging to genera genetically related to Haemophilus (such as Actinobacillus and Pasteurella) and species commonly isolated from the genital tract (Table 1). All $69 \mathrm{H}$. ducreyi strains and isolates, originating from 14 different geographical areas, showed the $197 \mathrm{bp}$ amplified fragment and were also positive with the rrs PCR. The 34 non-H. ducreyi organisms were all negative for both the ISR and rrs PCR assays.

\section{Evaluation of the ISR and rrs PCR on genital ulcer specimens}

Genital ulcer specimens from 28 patients with a clinical diagnosis of chancroid were cultured and analysed using both the $r r s-r r l$ ISR and the $r r s$ PCR assays. Identical results were obtained from both PCR assays. One of the 28 specimens was negative in culture and in both PCRs and was considered as clinically misdiagnosed. Of the remaining 27 specimens, $26(96 \%)$ were detected by both PCRs. One culture-positive sample was negative for both PCRs. The culture method was positive for 15 cases, indicating a sensitivity of $56 \%$.

\section{Evaluation of the ISR and rrs PCR on negative control groups}

Swabs from 32 patients with non-genital ulcers caused by different micro-organisms, genital swabs from 19 patients with non-chancroid STDs and vaginal swabs from 21 healthy females were collected as negative control groups. All 72 of these swabs were negative in both PCR assays.

\section{DISCUSSION}

In this study, the sequence of the intergenic region between the rrs (16S) and $r r l(23 S)$ genes of $H$. ducreyi was analysed, and used to develop a PCR assay for the detection of $H$. ducreyi in genital ulcer specimens. The one-tube heminested PCR described here offers a simple, highly specific and sensitive test with minimum risk of contamination. Although many studies have successfully used the rrs (16S) gene for typing and identification purposes, the gene is conserved throughout the Pasteurellaceae family (Dewhirst et al., 1992). We selected the region separating the $r r s$ and $r r l$ genes since this shows sequence variability and length polymorphism which should make it an ideal target for identifying eubacteria at the species level (Barry et al., 1991; Rossau et al., 1992; Rijpens et al., 1995; Gürtler \& Stanisch, 1996).

\section{Sequence analysis of the $\boldsymbol{H}$. ducreyi ISR}

We used two independent techniques to sequence the spacer region in an attempt to resolve the problems previously encountered, which were considered to be associated with its secondary structure. We obtained identical sequences from the ITM 5600 isolate by these two techniques. Only one nucleotide difference was observed between the ISR sequence of $H$. ducreyi CIP $542^{\mathrm{T}}$, isolated in Vietnam during the early $1950 \mathrm{~s}$, and ITM 5600, a clinical isolate from South Africa obtained in 1991. The H. ducreyi ITM 5600 ISR nucleotide sequence was compared with sequences in the GenBank, EMBL, DDBJ and PDB databases using the BLAST program (Altschul et al., 1997). The only similarity within the spacer region was to the tRNA ${ }^{\text {Giu }}$ sequence. In our PCR assay, we used three primers in a heminestedPCR strategy. Ideally, we needed pairs of primers with different annealing temperatures. The variability in the spacer region observed between $H$. ducreyi and closely related species allowed us to select one primer with a low annealing temperature for the first round of amplification, and two primers with higher annealing temperatures for the second round. Each of the three primers is specific for the detection of $H$. ducreyi, in contrast to a previous study where only one primer was specific and the others could anneal to DNA from many members of the Pasteurellaceae family. The results of the heminested PCR performed on $H$. ducreyi and non$H$. ducreyi strains and isolates confirm that the ISR of $H$. 


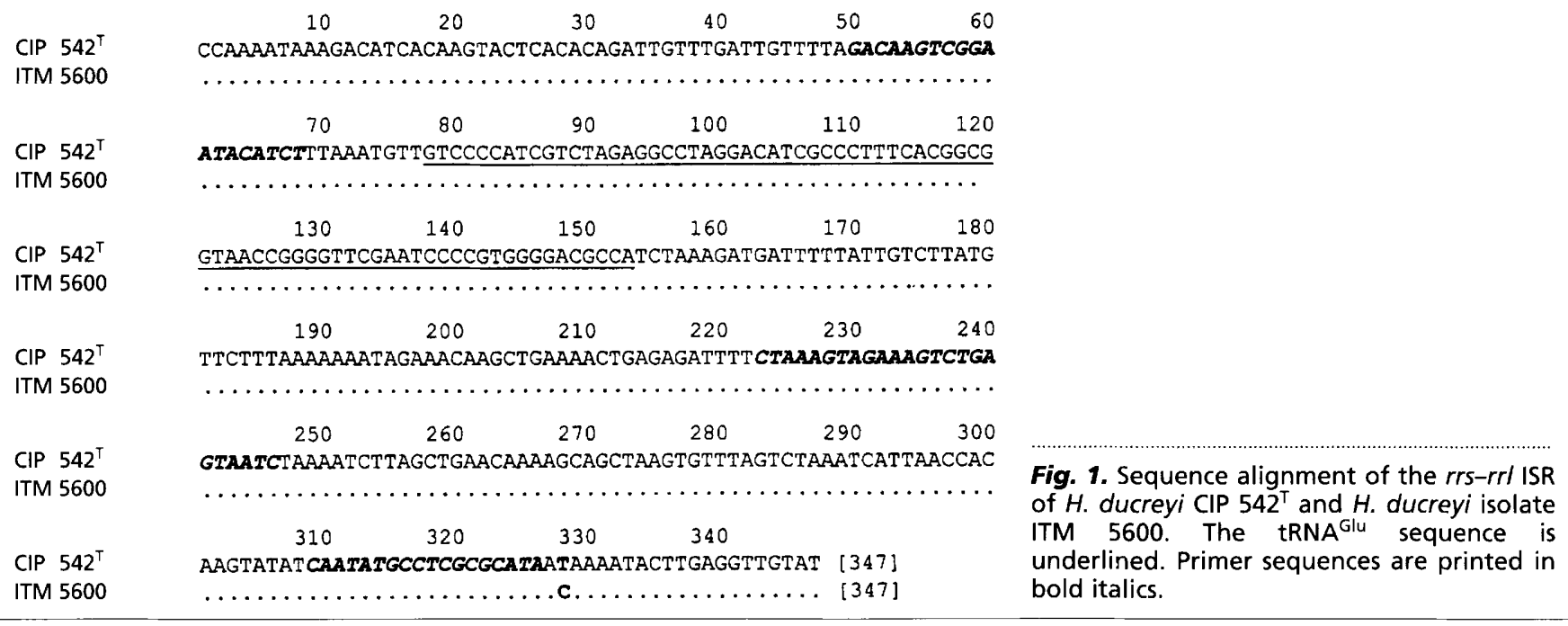

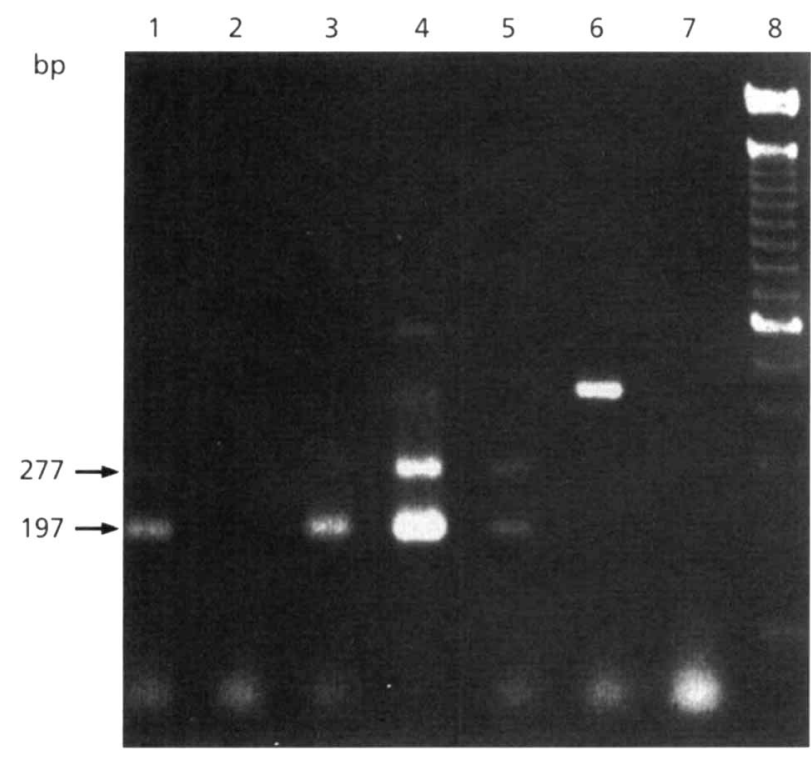

Fig. 2. Ethidium bromide stained agarose gel displaying the results of $r r s-r r$ ISR heminested PCR on genital ulcer specimens collected from South Africa. Lanes $1-3$ and 5, genital ulcer specimens; lane 4, $H$. ducreyi CIP $542^{\top}$; lane $6, H$. influenzae isolate ITM 4473; lane 7, negative control (no DNA); lane 8, 100 bp DNA ladder.

ducreyi is highly conserved at the species level but differs from that of other micro-organisms, including species belonging to the genera Haemophilus, Pasteurella, and Actinobacillus, genetically related to H. ducreyi (Rossau et al., 1991; Dewhirst et al., 1992).

\section{Detection of $\boldsymbol{H}$. ducreyi by PCR}

DNA amplification techniques are becoming reference methods for the detection of slow-growing and fastidious pathogenic micro-organisms. Several H. ducreyispecific PCR assays have recently been described. Chui

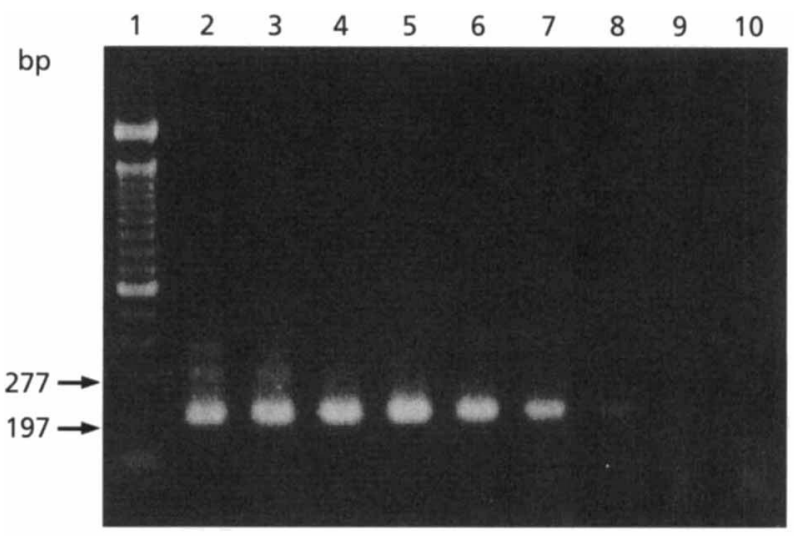

Fig. 3. Ethidium bromide stained agarose gel displaying the analytical sensitivity of ISR heminested PCR. Lane 1, 100 bp DNA ladder; lanes 2-9, PCR products of DNA diluted from $50 \mathrm{ng}$ to $5 \mathrm{fg}$ by 10 -fold dilutions; lane 10 , negative control (no DNA).

et al. (1993) used broad primers on the rrs gene and two $H$. ducreyi-specific probes internal to this sequence. Depending on the number of cycles of amplification, they obtained sensitivities of $83 \%$ and $98 \%$ and specificities of $67 \%$ and $51 \%$ relative to culture. Johnson et al. (1994, 1995) developed a PCR assay with two primers selected from the sequences of an anonymous fragment of DNA cloned from $H$. ducreyi. A 1100 bp PCR product was detected by Southern blotting and hybridization to a ${ }^{32} \mathrm{P}$-labelled probe consisting of the entire sequence. In a first study (Johnson et al., 1994), they observed a sensitivity of $62 \%$ and a specificity of $52 \%$ relative to culture techniques. By modifying sample preparation, they found a sensitivity of $100 \%$ and a specificity of $84 \%$ compared with culturing (Johnson et al., 1995). West et al. (1995) described a simplified $r r s$-based one-tube nested PCR. The inner primers were labelled with biotin and digoxigenin, and the PCR products were detected using an ELISA. Compared to clinical diagnosis, this assay 
showed a sensitivity of $83 \%$ while culture techniques showed a sensitivity of $77 \%$.

The sensitivities and specificities observed in the PCR studies cited above are rough estimates since culturing was usually used in the denominator. The relatively low PCR specificities may reflect the poor sensitivity of the $H$. ducreyi culture in these studies. Evaluation of the accuracy of a PCR assay requires comparison with another DNA amplification method, targeting a different gene. Parsons et al. (1995) described a H. ducreyi PCR using the groEL gene as target, and used a confirmatory PCR as described by Johnson et al. (1994). They amplified a 505 bp fragment and detected the products by Southern blotting and hybridization with a ${ }^{32}$ P-labelled internal oligonucleotide probe. The estimated sensitivity of the groEL PCR, compared with culturing and partially with the confirmatory PCR, was $92 \%$. Orle et al. (1996) described a multiplex PCR for the simultaneous amplification of DNA targets from $H$. ducreyi, Treponema pallidum, and herpes simplex virus. Biotinylated primers targeting the rrs gene of $H$. ducreyi were used to amplify a $440 \mathrm{bp}$ fragment, and colorimetric detection was performed using an internal capture probe. The groEL PCR described by Parsons et al. (1995) was used for confirmation. After discrepant analysis, the sensitivities were $98 \%$ for PCR and $74 \%$ for culture techniques.

In this study, a heminested-PCR protocol was designed to enhance the sensitivity of the assay. Three specific PCR primers, targeting a unique sequence of $r r s-r r l$ ISR of $H$. ducreyi, were used to avoid non-specific amplification when the number of cycles is greater than 35 . The specificity analysis of each primer was performed with the FASTDB program. No $100 \%$ homologous sequence, other than the H. ducreyi sequence, was found in GenBank. Similarity with other species is only found outside the region of the primers. With this ISR heminested-PCR assay, a sensitivity and a specificity of $100 \%$ was obtained using cultured samples. We modified the method described by West et al. (1995) for use as a confirmatory test. We found that insufficient $H$. ducreyi specific product was generated to be detected consistently by agarose gel electrophoresis unless the concentration of specific primer was increased 1000 -fold over the value given in the published method. Using this modification we observed $100 \%$ concordance between the two protocols. Therefore, the use of a second PCR assay targeting a different gene has the potential to become a 'gold standard' method for confirmation of $H$. ducreyi infection.

We used samples from a geographical region with a high relative prevalence of chancroid (Pham-Kanter et al., 1996) and where diagnostic accuracy is reported to be $80 \%$ (Dangor et al., 1990). The results of our assay were compatible with clinical diagnosis, with a sensitivity of $93 \%(26 / 28)$ and a specificity of $100 \%(72 / 72)$. Both PCR protocols gave identical results. Of the two discordant samples, the first, which was positive by clinical criteria but negative in both PCR assays and also by culturing, was considered to be the result of a misdiagnosis. The second sample was positive by culturing, although the isolate was no longer available, so we could not confirm whether our primers could have recognized it. However, the presence of non-specific inhibitors of PCR amplification was excluded, by the amplification of human $\beta$-globin gene when human DNA was added to the sample together with the necessary primers. Perhaps our failure to detect $H$. ducreyi in this sample was due to an uneven distribution of bacterial cells in the lesion or an insufficient amount of target DNA on this particular swab. The detection limit of the ISR PCR after gel electrophoresis was approximately $50 \mathrm{fg}$ (Fig. 3), which corresponds to about 25 genome-equivalents. This specimen might have contained a low concentration of DNA which could not be detected on an ethidium bromide stained agarose gel. We expect that detection of the PCR products using other systems may enhance the ISR PCR sensitivity without decreasing its specificity.

Using agarose gel electrophoresis for detection, the ISR PCR assay showed a sensitivity of $96 \%(26 / 27)$ on genital ulcer specimens from patients with clinically diagnosed chancroid, compared to a sensitivity of $56 \%$ $(15 / 27)$ for culture methods. The results indicated that the sequence of the $r r s-r r l$ intergenic spacer region can be used as a target for PCR amplification for the specific detection of $H$. ducreyi. The DNA extraction method from dried swabs was rapid and easy to perform. Detection by agarose gel electrophoresis is also cheaper than other methods and can be performed with equipment which is readily available in laboratories of developing countries. A preliminary evaluation on clinical specimens confirmed that a one-tube ISR heminested-PCR protocol is a rapid, reliable and convenient method for confirmatory laboratory diagnosis of chancroid.

\section{ACKNOWLEDGEMENTS}

We would like to extend our appreciation to all the colleagues who supported us in this study. Special thanks go to Professor F. Portaels for providing negative control specimens from patients with non-genital ulcer skin diseases and to Dr M. Vandenbruaene and Dr K. Depraetere for collecting the clinical swabs at the STD clinic of Institute of Tropical Medicine in Belgium. We acknowledge F. Shapiro for critical comments on the manuscript, and $\mathrm{K}$. Janssens for typing. This study was supported by a grant of the Swedish International Development Cooperation Agency.

\section{REFERENCES}

Ahmed, H. J., Borelli, S., Jonasson, J. \& 8 other authors (1995). Monoclonal antibodies against Haemophilus ducreyi lipooligosaccharide and their diagnostic usefulness. Eur J Clin Microbiol Infect Dis 14, 892-898.

Altschul, S. F., Madden, T. L., Schöffer, A. A., Zhang, J., Zhang, Z., Miller, W. \& Lipman, D. J. (1997). Gapped BLAST and PSI-BLAST : a new generation of protein database search programs. Nucleic Acids Res 25, 3389-3402. 
Barry, T., Colleran, G., Glennon, M., Dunican, L. K. \& Gannon, F. (1991). The $16 \mathrm{~S} / 23 \mathrm{~S}$ ribosomal spacer region as a target for DNA probes to identify eubacteria. PCR Methods Appl 1, 51-56.

Chui, L., Albritton, W., Paster, B., Maclean, I. \& Marusyk, R. (1993). Development of the polymerase chain reaction for diagnosis of chancroid. J Clin Microbiol 31, 659-664.

Choudhary, B. P., Kumari, S., Bhatia, R. \& Agarwal, D. S. (1982). Bacteriological study of chancroid. Ind J Med Res 76, 379-385.

Dangor, Y., Ballard, R. C., Exposto, F. d. L., Fehler, G., Miller, S. D. \& Koornhof, H. J. (1990). Accuracy of clinical diagnosis of genital ulcer disease. Sex Transm Dis 17, 184-189.

Dangor, Y., Miller, S. D., Koornhof, H. J. \& Ballard, R. C. (1992). A simple medium for the primary isolation of Haemophilus ducreyi. Eur J Clin Microbiol Infect Dis 11, 930-934.

Dangor, Y., Radebe, F. \& Ballard, R. C. (1993). Transport media for Haemophilus ducreyi. Sex Transm Dis 20, 5-9.

Dewhirst, F. E., Paster, B. J., Olsen, I. \& Fraser, G. J. (1992). Phylogeny of 54 representative strains of species in the family Pasteurellaceae as determined by comparison of $16 \mathrm{~S}$ rRNA sequences. J Bacteriol 174, 2002-2013.

Fast, M. V., D'Costa, L. J., Nsanze, H., Piot, P., Curran, J., Karasira, P., Mirza, N., Maclean, I. W. \& Ronald, A. R. (1984). The clinical diagnosis of genital ulcer disease in men in the tropics. Sex Transm Dis 11, 72-76.

Fleischmann, R. D., Adams, M. D., White, O. \& 37 other authors (1995). Whole-genome random sequencing and assembly of Haemophilus influenzae Rd. Science 269, 496-511.

Grosskurth, H., Mosha, F., Todd, J. \& 11 other authors (1995). Impact of improved treatment of sexually transmitted diseases on HIV infection in rural Tanzania: randomised controlled trial. Lancet 346, 530-536.

Gurtler, V. \& Stanisch, V. A. (1996). New approaches to typing and identification of bacteria using the $16 \mathrm{~S}-23 \mathrm{~S}$ rDNA spacer region. Microbiology 142, 3-16.

Jensen, M. A., Webster, J. A. \& Straus, N. (1993). Rapid identification of bacteria on the basis of polymerase chain reactionamplified ribosomal DNA spacer polymorphisms. Appl Environ Microbiol 59, 945-952.

Jessamine, P. G., Plummer, F. A., Ndinya-Achola, J. O. \& 7 other authors (1990). Human immunodeficiency virus, genital ulcers and the male foreskin: synergism in HIV-1 transmission. Scand J Infect Dis Suppl 69, 181-186.

Johnson, S. R., Martin, D. H., Cammarata, C. \& Morse, S.A. (1994). Development of a polymerase chain reaction assay for the detection of Haemophilus ducreyi. Sex Transm Dis 21, 13-23.

Johnson, S. R., Martin, D. H., Cammarata, C. \& Morse, S. A. (1995). Alterations in sample preparation increase sensitivity of PCR assay for diagnosis of chancroid. J Clin Microbiol 33, 1036-1038.

Karim, H., Easmon, F. G., Dangor, Y., Dance, D., Ngeow, Y. \& Ballard, R. C. (1989). Rapid detection of Haemophilus ducreyi in clinical and experimental infections using monoclonal antibody: a preliminary evaluation. Genitourin Med 65, 361-365.

Kreiss, J. K., Coombs, R., Plummer, F., Holmes, K. K., Nikora, B., Cameron, W., Ngugi, E., Ndinya-Achola, J. O. \& Corey, L. (1989).
Isolation of human immunodeficiency virus from genital ulcers in Nairobi prostitutes. J Infect Dis 160, 380-384.

Morse, S. A. (1989). Chancroid and Haemophilus ducreyi. Clin Microbiol Rev 2, 137-157.

Orle, K. A., Gates, C. A., Martin, D. H., Body, B. A. \& Weiss, J. B. (1996). Simultaneous PCR detection of Haemophilus ducreyi, Treponema pallidum, and herpes simplex virus types 1 and 2 from genital ulcers. $J$ Clin Microbiol 34, 49-54.

Ortiz-Zepeda, C., Hernandez-Perez, E. \& Marroquin-Burgos, R. (1994). Gross and microscopic features in chancroid: a study in 200 new culture-proven cases in San Salvador. Sex Transm Dis 21, 112-117.

Parsons, L. M., Waring, A. L., Otido, J. \& Shayegani, M. (1995). Laboratory diagnosis of chancroid using species-specific primers from Haemophilus ducreyi groEL and the polymerase chain reaction. Diagn Microbiol Infect Dis 23, 89-98.

Pham-Kanter, G. B. T., Steinberg, M. H. \& Ballard, R. C. (1996). Sexually transmitted diseases in South Africa. Genitourin Med 72, 160-171.

Plummer, F. A., Simonsen, J. N., Cameron, D. W. \& 8 other authors (1991). Cofactors in male-female sexual transmission of human immunodeficiency virus type 1 . J Infect Dis 163, 233-239.

Rijpens, N. P., Jannes, G., Van Asbroeck, M., Herman, L. M. F. \& Rossau, R. (1995). Simultaneous detection of Listeria spp. and Listeria monocytogenes by reverse hybridization with $16 \mathrm{~S}-23 \mathrm{~S}$ rRNA spacer probes. Mol Cell Probes 9, 423-432.

Roggen, E. L., Pansaerts, R., Van Dyck, E. \& Piot, P. (1993). Antigen detection and immunological typing of Haemophilus ducreyi with a specific rabbit polyclonal serum. J Clin Microbiol 31, 1820-1825.

Rossau, R., Duhamel, M., Jannes, G., Decourt, J. L. \& Van Heuverswyn, H. (1991). The development of specific rRNAderived oligonucleotide probes for Haemophilus ducreyi, the causative agent of chancroid. J Gen Microbiol 137, 277-285.

Rossau, R., Michielsen, A., Jannes, G., Duhamel, M., Kerstens, K. \& Van Heuverswijn, H. (1992). DNA probes for Bordetella species and a colorimetric reverse hybridisation assay for the detection of Bordetella pertussis. Mol Cell Probes 6, 281-289.

Sambrook, J., Frisch, E. F. \& Maniatis, T. (1989). Molecular Cloning: a Laboratory Manual, 2nd edn. Cold Spring Harbor, NY: Cold Spring Harbor Laboratory.

Taylor, D. N., Duangmani, C., Suvongse, C., O'Connor, R., Pitarangsi, C., Panikabutra, K. \& Echeverria, P. (1984). The role of Haemophilus ducreyi in penile ulcers in Bangkok, Thailand. Sex Transm Dis 11, 148-151.

Trees, D. L. \& Morse, S. A. (1995). Chancroid and Haemophilus ducreyi: an update. Clin Microbiol Rev 8, 357-375.

West, B., Wilson, S. M., Changalucha, J., Patel, S., Mayaud, P., Ballard, R. C. \& Mabey, D. (1995). Simplified PCR for detection of Haemophilus ducreyi and diagnosis of chancroid. J Clin Microbiol 33, 787-790.

Received 11 August 1997; revised 22 October 1997; accepted 4 December 1997. 